\section{No immunity for Moscow}

\section{Moscow}

Computers in the Soviet Union have been suffering from virus infections just as in the United States and Western Europe. In one of the most recent cases, at the Institute of Applied Mathematics of the Soviet Academy of Sciences, researchers found that some of their programs were disappearing for no apparent reason shortly after retrieval. Their computers had been attacked by a virus. The rogue program was quickly found and killed.

Virus infection is not new. About 20 years ago, programmers at a research institute were annoyed by the erratic behaviour of an ICL computer, The institute was on the point of sending for help from the British supplier when a young programmer admitted having written a program that fooled the operating system while remaining invisible.

With the advent of personal computers, a little too late in the Soviet Union, programmers have been confronted with a formidable job of developing anti-viral codes. The first Soviet machines to suffer from viral infections, ostensibly imported from the West, were Atari computers, followed by IBM-compatible machines.

By the time the International Computer Club was formed in Moscow last December, Soviet programmers had compiled a list of lethal files, including viruses and socalled "Trojan" programs. A user with such a list can identify the infection but cannot cure it. It takes a special anti-viral program to purge the virus.

There are now some 40 virus programs on the Soviet danger list and the number continues to grow. The computer epidemic is spreading because of the woefully inadequate software distribution system in the Soviet Union - or rather because of the lack of any such system. The result is that most Soviet programmers are engaged in entirely disorganized computer activities, seeking casual contacts with colleagues.

\section{Gorbachev's first Chernobyl visit since disaster}

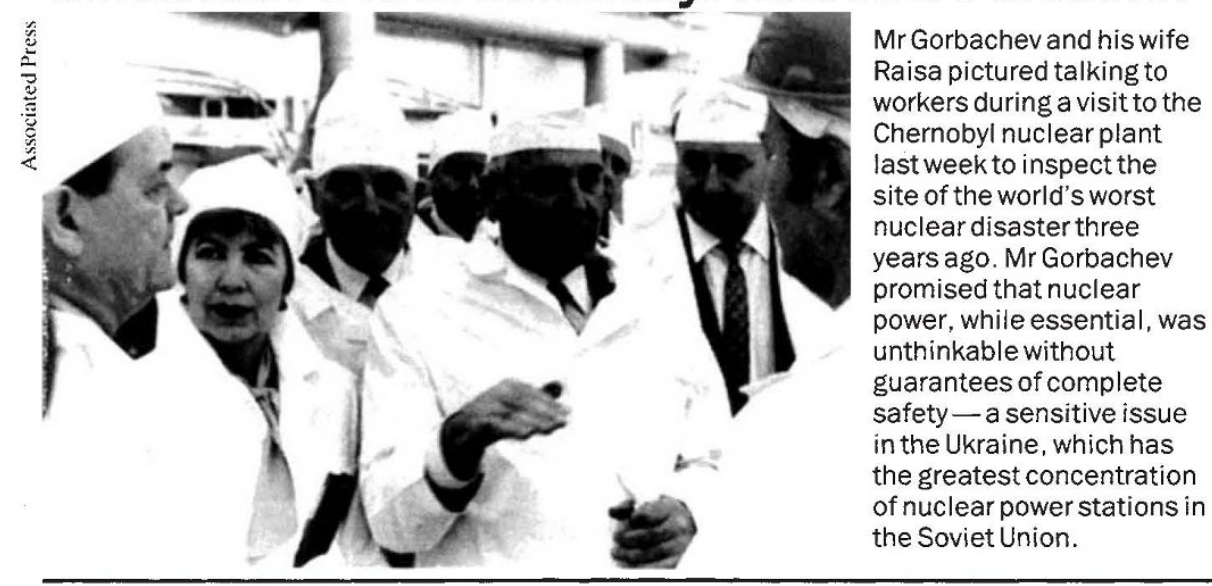

With no official software market, such contacts are the only way to obtain software in high demand. Among several hundred of my acquaintances who work with software best-sellers, only a handful have bought them legally.

There is no evidence that specific Soviet computer viruses have been, or are being, developed. Indeed, the best Soviet programmers are said to be working on a computer "vaccine". Such a program was described by the central Soviet newspapers last autumn. The idea is that the program identifies a constant part of a known virus and removes it from the host program. But such programs are not universal, as they purge only well-known viruses with 'recognition sites'.

Apart from rudimentary restriction programs, there are two anti-viral 'vaccines' in the Soviet Union. The first is a resident program monitoring a computer's 'abnormal' behaviour, which may suggest that a virus attack is under way. The other may seem more attractive to users in that it is not memory-resident and may be run after a series of operations to give a programmer a list of files which may have been modified by a virus.

Having analysed the suspicious programs the programmers can tell whether the computer system has been infected. One difficulty is that the incubation periods may be very long so that the owner of the damaged machine may discover a new infection.

Worse still, until recently there was no popular magazine for programmers, so that news about viral attacks was spread by word of mouth. The most lethal viruses, which are spread by networks, pose no danger to Soviet computers; there are almost no computer networks in the Soviet Union. Meanwhile, the need for computer virologists and for joint efforts with Western colleagues is increasingly evident.

Pavel Pevzner Novosti
Greenpeace's
claims refuted

\section{Paris}

THE director of the research mission of the French department for Austral and Antarctic Territories (TAAF) has rejected claims by the environmental group Greenpeace that an airstrip being constructed in the French Antarctic Territory contravenes the Antarctic Treaty (see Nature 337, 106; 1988). Bernard Morlet says the airstrip is being built to support scientific research, and that steps are being taken to ensure that colonies of Emperor and Adélie penguins are not endangered by construction work.

Plans to build an airstrip at Dumont d'Urville date back to 1983 , and are prompted by seasonal restrictions on sea access to the French base, which is surrounded by several hundred square miles of pack-ice in winter. Ships can first reach the base at mid-summer in December, and researchers arriving in January, when the base has been made habitable, have only a month to collect data if they are to avoid being icebound. An airstrip, says Morlet, will allow researchers to winter at the base and to begin work - in human and animal physiology, glaciology and climatology - once summer begins.

According to Greenpeace, the airstrip has destroyed breeding grounds for a colony of Adélie penguins and blocked the migratory path of Emperor penguins. But Morlet says that the migratory path of the Emperor penguins is variable, so that the construction may pose no problem at all, and that, in any case, they are used to climbing onto sea islands to avoid winter storms and so should be able to surmount the airstrip, which is only 5 metres above sea level.

Morlet does acknowledge that the breeding ground of the Adélie penguin, jeopardized by the landing strip, is a problem, but says that the effect of the construction project can be minimized by protecting the adult population and encouraging a change in breeding. He says that the material used for the airstrip may help to create new breeding sites. He also accuses Greenpeace of misreading the Antarctic Treaty. While its third (1983) revision forbids harmful interference with bird and seal colonies - by the use of explosives or by disturbance during their breeding periods - it also allows these activities "...to the minimum extent necessary for the establishment, supply and operation of stations".

Morlet also rejects Greenpeace's allegation that the airstrip is a foot in the door for mineral exploitation. He says that the 2,000-metre icepack beneath the French base makes it unsuitable for this purpose.

Peter Coles 